\title{
Spray Drying of Pequi Pulp: Process Performance and Physicochemical and Nutritional Properties of the Powdered Pulp
}

\author{
Audirene Santana ${ }^{1,3}$, Louise Kurozawa ${ }^{2 *}$, Rafael Oliveira ${ }^{1}$ and Kil Park ${ }^{1}$ \\ ${ }^{1}$ Faculdade de Engenharia Agrícola; Universidade Estadual de Campinas; Campinas - SP - Brasil. ${ }^{2}$ Departamento \\ de Ciência e Tecnologia de Alimento; Universidade Estadual de Londrina; Londrina - PR - Brasil. ${ }^{3}$ Faculdade de \\ Engenharia Química; Universidade Federal do Maranhã; São Luis - MA - Brasil
}

\begin{abstract}
The objective of this work was to optimize the spray drying of pequi pulp using maltodextrin as carrier agent and Tween 80 as surfactant agent. A central composite rotatable design was used to evaluate the influence of inlet air temperature $\left(140\right.$ to $\left.200^{\circ} \mathrm{C}\right)$, maltodextrin $(15$ to $30 \%)$ and surfactant $(0$ to $5 \%)$ concentration on the process performance and physicochemical and nutritional properties of the dried powdered pulp. The dependent variables were process yield $(27.4-51.7 \%)$, outlet air temperature $\left(106.5-135^{\circ} \mathrm{C}\right)$, energetic efficiency $(29.9-44.8 \%)$, moisture content (0.25 - 1.43\%), water activity (0.09 to 0.21), hygroscopicity (9.1 - $12.1 \mathrm{~g}$ adsorbed moisture/100g dry matter), vitamin C content (129.8 - $303.0 \mathrm{mg} / \mathrm{g}$ solids pequi) and total carotenoids content ( 8.2 - $94.9 \mathrm{mg}$ carotenoids $/ \mathrm{g}$ solids pequi). The spray drying of pequi pulp was optimized for maximum vitamin $C$ and total carotenoids content using response surface methodology, which were attained at $152^{\circ} \mathrm{C}$, surfactant concentration of $1 \%$ and maltodextrin concentration of $18 \%$. The characterization of the pequi pulp powder obtained at the optimized condition evaluating the particles sizes, bulk density and porosity. The morphology showed spherical and smooth particles with several sizes.
\end{abstract}

Key words: Fruit, Tween 80 , powder property, screening design, microscopy

\section{INTRODUCTION}

Due to the attractive commercial point of view, a huge amount of fruits and vegetables is produced in the tropical and subtropical countries. Most of these products possess high water activity, making them susceptible to decomposition by the microorganisms, chemical and enzymatic reactions. Since these products are extremely perishable, associated with the seasonal problem, they are difficult to be marketed, or exported as fresh produce.

In Brazil, the loss of tropical and subtropical fruits is significant, reaching about 5 million ton/year
(Soares 2009). Among these fruits, there is the pequi (Caryocar brasiliense Camb), a typical fruit of the Brazilian savanna region, or "cerrado". This fruit, which contains 1 to 4 seeds under a pasty, oleaginous and yellow pulp, is rich in oil, carbohydrates, proteins and phytochemicals substances such as carotenoids and vitamins $\mathrm{A}$ and C (Teixeira 2008).

Vitamin $\mathrm{C}$ is very important for human nutrition, since is an essential substance that prevents diseases such as scurvy, and it plays the role of biological antioxidant. As humans have no capability to synthesize this vitamin, it should then be supplied by the diet (Santos and Silva 2008). Appreciated for

*Author for correspondence: louisek98@yahoo.com.br 
the pleasing yellow, orange, or red color they impart to many foods, carotenoids are also natural antioxidants and as such contribute to the stability of foods. In addition, apart from the provitamin A activity, carotenoids can prevent, or reduce the risk of various disorders in humans and animals and exert physiological benefits when consumed such as cardiovascular and eye diseases prevention and anticancer activity (Krinsky and Johnson 2005; Rodrigues-Amaya 2010). However, these nutrients are generally susceptible to degradation reactions during the processing and storage, due to their sensitivity to adverse environmental conditions and food matrix such as temperature, $\mathrm{pH}$, light, time, and presence of enzymes, oxygen and metallic catalysers.

In this context, spray drying represents an alternative to improve the conservation of the final product, which facilitates the storage, handling, and transportation of the product. Due to the short residence time, this drying method is suitable for heat-sensitive products, promoting higher retention of flavor, color, and nutrients. The physicochemical and nutritional properties of spray-dried powder depends on the characteristics of the feed solution (viscosity, flow rate) and the drying air (temperature, pressure, air flow), contact between the hot air and droplets in the drying chamber (concurrent, or countercurrent flow), and the type of atomizer used (Masters 1991). According to Barbosa-Cánovas et al. (2005), it is essential to optimize the spray drying process, aiming to reduce the cost and to obtain the products with better sensory and nutritional characteristics.

Since fruit juices contain sugars and acids of low molecular weight, they present low glass transition temperature ( $\mathrm{Tg})$ and, consequently, high stickiness. Thus, they can stick on the dryer chamber wall during the drying, leading to low product recovery and operational problems. Due to the high $\mathrm{Tg}$ value of maltodextrin $\left(205^{\circ} \mathrm{C}\right.$, according to Roos and Karel 1991), its addition has been used in the production of powders, reducing the hygroscopicity, stickiness and wall deposition (Roos and Karel 1991). Maltodextrins have been widely used for the microencapsulation of food ingredients susceptible to the deterioration by external agents. Their advantages are low cost, neutral flavor, low viscosity at high solids concentrations and good protection against oxidation. However, the biggest problem of this microencapsulating agent is its low emulsifying capacity.
As pequi pulp presents high lipid content (approximately $30 \%$ on wet basis), it is necessary to obtain a stable emulsion between the lipid phase and maltodextrin aqueous solution, in order to have an effective spray drying process. Therefore, the use of maltodextrin in combination with other surface active biopolymers overcomes this problem. Tween 80 (polyoxyethylene sorbitan monooleate), one of the most commonly used water-dispersible non-ionic surfactants, is widely used in food emulsions as it can stabilize the emulsion for a short period by reducing the oilwater interfacial tension. The total concentration of emulsifier present in the system is crucial for the stability of droplets because there must be a sufficient quantity available to completely cover all the droplets formed in the emulsion (McClements 2005).

The objective of this work was to study the influence of inlet air temperature, surfactant (Tween 80) concentration and carrier agent (maltodextrin 10DE) concentration on dryer performance, physicochemical and nutritional properties powder. The specific objectives were (1) to optimize the microencapsulation process aiming high nutritional retention; and (2) to characterize the microcapsules obtained under the optimized condition with respect to bulk and absolute densities, porosity, particles size distribution and morphology.

\section{MATERIAL AND METHODS}

\section{Material}

Pequi fruits were acquired from the Cooperative of Grande Sertão Ltda (Montes Claros, Minas Gerais, Brazil). The fruits were stored at $5 \pm 1{ }^{\circ} \mathrm{C}$ and relative humidity of $90-95 \%$. They were dipped in a sodium hypochlorite solution $(200 \mathrm{mg} / \mathrm{L})$ for $15 \mathrm{~min}$ and manually peeled. The internal mesocarp was grated to obtain the pulp, which was homogenized with distilled water (pulp:water ratio 1:2.5, w/w). The pulp was stored in a freezing chamber at $-18^{\circ} \mathrm{C}$ and thawed according to the quantity required for spray drying. The main characteristics of pequi pulp (on wet basis), obtained according to AOAC (2006), were: moisture content of $52.33 \pm 0.02 \%$, fat content of $30.66 \pm 0.75 \%$, protein content of $5.08 \pm 0.03 \%$, ash content of $1.22 \pm 0.001 \%$, carbohydrate content of $10.71 \pm 1.05 \%$, reducing sugar content of $5.04 \pm 0.71 \%$ and $338.38 \pm 1.06 \mathrm{mg}$ vitamin $\mathrm{C} / \mathrm{g}$ solids of pequi. Carotenoids content $(140.69 \pm 0.08$ 
mg carotenoids/g solids of pequi) was obtained according to Rodrigues-Amaya (1999). For the spray drying process, maltodextrin Mor-rex ${ }^{\circledR} 1910$ with DE 10 (Corn Products, São Paulo, Brazil) was used as carrier agent and polyoxyethylene sorbitan monooleate (Tween 80) (Synth, Brazil) as surfactant agent.

\section{Spray Drying}

Before the spray drying process, pequi pulp was diluted with distilled water (pulp:water ratio 1:2, $\mathrm{w} / \mathrm{w}$ ) and filtered through a qualitative filter paper. The filtrate presented $12.8 \%$ of solids content. The purpose of this procedure was to remove suspended particulates solids, avoiding obstruction of the atomizer nozzle of spray dryer. Maltodextrin and Tween 80 were added directly to the filtered mixture at several concentrations according to the Table 1. The homogenization was carried out in an ultra-turrax homogenizer (Extratur Disperser, Quimis, Brazil) operating at $14,000 \mathrm{~g}$ for $10 \mathrm{~min}$.

For spray drying experiments, a laboratory spray dryer was used (model B191, Büchi, Flawil, Switzerland). The equipment was operated concurrently using a spray nozzle with an orifice of $0.7 \mathrm{~mm}$ in diameter. The drying chamber had a diameter of $110 \mathrm{~mm}$ and a height of $435 \mathrm{~mm}$. The mixture was fed into the drying chamber using a peristaltic pump. The feed mass flow rate and compressed air flow rate were $0.2 \mathrm{~kg} / \mathrm{h}$ and 0.6 $\mathrm{m}^{3} / \mathrm{h}$, respectively. The tests were performed under different conditions with respect to inlet air temperature $\left(140-200^{\circ} \mathrm{C}\right)$, maltodextrin $10 \mathrm{DE}$ concentration $(15-30 \%$, weight of maltodextrin/weight of filtered pequi pulp) and surfactant concentration $(0-5 \%$, weight of surfactant/weight of filtered pequi pulp), according to Table 1.

\section{Experimental Design}

A central composite rotational design (CCRD) $2^{3}$ (Table 1) was used to evaluate the effect of the independent variables inlet air temperature $\left(\mathrm{T}_{\mathrm{in}}\right)$, surfactant Tween 80 concentration (SC) and carrier agent maltodextrin concentration (MC) on the responses dryer performance (process yield, outlet air temperature and energetic efficiency), powder physicochemical properties (moisture content, hygroscopicity and water activity) and powder nutritional properties (vitamin $\mathrm{C}$ and total carotenoids content).

The experimental data were fitted to the following polynomial equation:

$$
\begin{aligned}
Y= & \beta_{0}+\beta_{1} X_{1}+\beta_{2} X_{2}+\beta_{3} X_{3}+\beta_{11} X_{1}^{2}+\beta_{22} X_{2}^{2}+ \\
& \beta_{33} X_{3}^{2}+\beta_{12} X_{1} X_{2}+\beta_{13} X_{1} X_{3}+\beta_{23} X_{2} X_{3}
\end{aligned}
$$

where $Y$ is the response (dependent variable); $\beta_{0}$, is the constant regression coefficient; $\beta_{1}, \beta_{2}$, and $\beta_{3}$ are the linear regression coefficients; $\beta_{11}, \beta_{22}$, and $\beta_{33}$ are the quadratic regression coefficients; $\beta_{12}, \beta_{13}$ and $\beta_{23}$ are the cross-product regression coefficients; $\mathrm{X}_{1}, \mathrm{X}_{2}$, and $\mathrm{X}_{3}$ represent the coded values of the independent variables (inlet air temperature, surfactant concentration, and maltodextrin concentration, respectively).

In order to obtain the regression coefficients, an analysis of variance (ANOVA) was carried out using the Statistica 9.0 (Statsoft, Tulsa, USA) software package. Only variables with a confidence level above $90 \% \quad(\mathrm{p} \leq 0.10)$ were considered significant.

For carotenoid and vitamin $\mathrm{C}$ content responses, the factorial screening design $2 \mathrm{k}$ (related to design points 1 to 8 ), including central points (design points 15 - 17), indicated that the predictive model was linear. Thus, it was not necessary to expand the factorial screening design for central composite rotatable design, with addition of axial points (points 9 to 14), because this design is applied when predictive model is quadratic.

\section{Analytical Methods}

\section{Drying Performance}

In order to evaluate the spray drying performance, process yield and energetic efficiency were calculated by Equations (2) and (3) (Cortés-Roja et al. 2005).

$$
\mathrm{Y}(\%)=\frac{\left(1-\mathrm{X}_{\text {powder }}\right) \times \mathrm{M}_{\text {powder }}}{\left(1-\mathrm{X}_{\text {feed }}\right) \times \mathrm{M}_{\text {feed }}} \times 100
$$

where $\mathrm{X}_{\text {powder }}$ is the water content in the powder $(\mathrm{kg}$ water $/ \mathrm{kg}$ powder), $\mathrm{X}_{\text {feed }}$ is the water content in the feed solution ( $\mathrm{kg}$ water $/ \mathrm{kg}$ feed), $\mathbf{M}_{\text {powder }}$ is the mass of powder $(\mathrm{kg})$ and $\mathrm{M}_{\text {feed }}$ is the mass of feed $(\mathrm{kg})$.

$$
\eta(\%)=\frac{\mathrm{T}_{\text {in }}-\mathrm{T}_{\text {out }}}{\mathrm{T}_{\text {in }}-\mathrm{T}_{\text {room }}} \times 100
$$

where $T_{\text {in }}, T_{\text {out }}$ and $T_{\text {room }}$ are inlet, outlet and room temperatures $\left({ }^{\circ} \mathrm{C}\right)$. 
Table 1 - Experimental design for the spray drying of pequi pulp powder.

\begin{tabular}{|c|c|c|c|c|c|c|c|c|c|c|c|}
\hline \multirow{3}{*}{$\begin{array}{c}\text { Design } \\
\text { point }\end{array}$} & \multicolumn{3}{|c|}{ Independent variables ${ }^{*}$} & \multicolumn{8}{|c|}{ Dependent variables } \\
\hline & \multirow[b]{2}{*}{$\begin{array}{c}\mathbf{T}_{\text {in }} \\
\left({ }^{\circ} \mathbf{C}\right)\end{array}$} & \multirow[b]{2}{*}{$\begin{array}{l}\text { SC } \\
(\%)\end{array}$} & \multirow[b]{2}{*}{$\begin{array}{l}\text { MC } \\
(\%)\end{array}$} & \multicolumn{3}{|c|}{ Process performance } & \multicolumn{3}{|c|}{ Physicochemical properties } & \multicolumn{2}{|c|}{ Nutritional properties } \\
\hline & & & & $\begin{array}{c}\mathbf{Y} \\
(\%)\end{array}$ & $\begin{array}{l}\mathbf{T}_{\text {out }} \\
\left({ }^{\circ} \mathbf{C}\right)\end{array}$ & $\begin{array}{c}\eta \\
(\%)\end{array}$ & $\mathbf{X}(\%)$ & $\mathbf{A}_{\mathbf{w}}$ & $\begin{array}{c}\text { H (g adsorbed } \\
\text { water } / 100 \mathrm{~g} \\
\text { solids) }\end{array}$ & $\begin{array}{c}\mathrm{VC}(\mathbf{m g} / \mathrm{g} \\
\text { solids } \\
\text { pequi) }\end{array}$ & $\begin{array}{c}\mathrm{CC} \\
\text { (mg/g solids } \\
\text { pequi) }\end{array}$ \\
\hline 1 & $152(-1)$ & $1(-1)$ & $18(-1)$ & 45.7 & $111.0 \pm 0.2$ & 32.7 & $0.89 \pm 0.003$ & $0.09 \pm 0.002$ & $10.1 \pm 0.001$ & $303.0 \pm 0.6$ & $94.9 \pm 0.003$ \\
\hline 2 & $188(1)$ & $1(-1)$ & $18(-1)$ & 44.8 & $140.0 \pm 0.1$ & 29.9 & $0.91 \pm 0.001$ & $0.10 \pm 0.01$ & $11.4 \pm 0.001$ & $258.6 \pm 0.8$ & $55.9 \pm 0.011$ \\
\hline 3 & $152(-1)$ & $4(1)$ & $18(-1)$ & 39.2 & $111.0 \pm 0.2$ & 33.4 & $0.55 \pm 0.001$ & $0.06 \pm 0.001$ & $10.89 \pm 0.001$ & $129.8 \pm 0.4$ & $60.4 \pm 0.002$ \\
\hline 4 & $188(1)$ & $4(1)$ & $18(-1)$ & 44.8 & $140.0 \pm 0.7$ & 30.4 & $1.05 \pm 0.001$ & $0.10 \pm 0.01$ & $12.0 \pm 0.001$ & $137.3 \pm 0.6$ & $42.1 \pm 0.03$ \\
\hline 5 & $152(-1)$ & $1(-1)$ & $27(1)$ & 37.7 & $110.0 \pm 0.5$ & 34.4 & $0.80 \pm 0.003$ & $0.08 \pm 0.003$ & $12.1 \pm 0.002$ & $251.3 \pm 0.1$ & $43.5 \pm 0.004$ \\
\hline 6 & $188(1)$ & $1(-1)$ & $27(1)$ & 48.7 & $135.0 \pm 0.4$ & 32.4 & $0.84 \pm 0.003$ & $0.13 \pm 0.01$ & $11.3 \pm 0.001$ & $263.8 \pm 0.3$ & $35.3 \pm 0.002$ \\
\hline 7 & $152(-1)$ & & $27(1)$ & 46.2 & $108.0 \pm 0.2$ & 34.9 & $1.11 \pm 0.002$ & $0.10 \pm 0.03$ & & $143.5 \pm 0.6$ & $20.2 \pm 0.01$ \\
\hline 8 & $188(1)$ & $4(1)$ & 27 (1) & & $132.0 \pm 0.1$ & 34.7 & $1.03 \pm 0.003$ & $0.14 \pm 0.01$ & $12.1 \pm 0.002$ & $164.7 \pm 0.7$ & $12.4 \pm 0.01$ \\
\hline 9 & $\begin{array}{c}140 \\
(-1.68)\end{array}$ & $2.5(0)$ & $22.5(0)$ & 38.9 & $99.0 \pm 0.2$ & 35.6 & $1.43 \pm 0.001$ & $0.18 \pm 0.01$ & $9.1 \pm 0.0001$ & - & 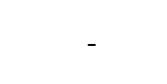 \\
\hline 10 & $\begin{array}{c}200 \\
(1.68)\end{array}$ & $2.5(0)$ & $22.5(0)$ & 46.2 & $140.0 \pm 0.4$ & 34.4 & $0.66 \pm 0.001$ & $0.14 \pm 0.01$ & $11.1 \pm 0.0003$ & - & - \\
\hline 11 & $170(0)$ & $0(-1.68)$ & $22.5(0)$ & 46.7 & $119.0 \pm 0.3$ & 35.5 & $0.65 \pm 0.001$ & $0.17 \pm 0.04$ & $11.2 \pm 0.002$ & - & - \\
\hline 12 & $170(0)$ & $5(1.68)$ & $22.5(0)$ & 34.0 & $117.0 \pm 0.2$ & 37.2 & $1.37 \pm 0.001$ & $0.14 \pm 0.01$ & $10.5 \pm 0.001$ & - & - \\
\hline 13 & $170(0)$ & $2.5(0)$ & $15(-1.68)$ & 51.7 & $111.0 \pm 0.4$ & 41.7 & $1.18 \pm 0.001$ & $0.21 \pm 0.02$ & $9.3 \pm 0.001$ & - & - \\
\hline 14 & $170(0)$ & $2.5(0)$ & $30(1.68)$ & 27.4 & $107.5 \pm 0.3$ & 44.2 & $0.25 \pm 0.001$ & $0.15 \pm 0.01$ & $10.4 \pm 0.001$ & - & - \\
\hline 15 & $170(0)$ & $2.5(0)$ & $22.5(0)$ & 42.2 & $106.5 \pm 0.2$ & 44.8 & $0.26 \pm 0.001$ & $0.13 \pm 0.02$ & $12.0 \pm 0.001$ & $185.9 \pm 0.9$ & $30.8 \pm 0.01$ \\
\hline 16 & $170(0)$ & $2.5(0)$ & $22.5(0)$ & 42.9 & $110.0 \pm 0.1$ & 41.5 & $0.25 \pm 0.001$ & $0.13 \pm 0.02$ & $12.1 \pm 0.005$ & $184.8 \pm 0.8$ & $30.5 \pm 0.01$ \\
\hline 17 & $170(0)$ & $2.5(0)$ & $22.5(0)$ & 42.1 & $110.0 \pm 0.2$ & 41.7 & $0.29 \pm 0.001$ & $0.14 \pm 0.01$ & $12.1 \pm 0.001$ & $185.2 \pm 0.8$ & $30.5 \pm 0.01$ \\
\hline
\end{tabular}

*The independent variables correspond to the real values. Values enclosed in parentheses correspond to the coded values.

\section{Moisture Content $(X)$ and Water activity $\left(A_{w}\right)$}

Powder moisture content was determined gravimetrically using a vacuum oven at $70^{\circ} \mathrm{C}$ until constant weight. Feed solution moisture content was determined using a forced air circulation oven at $60^{\circ} \mathrm{C}$ during $24 \mathrm{~h}$ and then a vacuum oven at $70^{\circ} \mathrm{C}$ until constant weight (AOAC 2006). A Decagon (Pawkit model, Aqualab, USA) was used to measure the water activity at $25^{\circ} \mathrm{C}$.

\section{Hygroscopicity $(H)$}

Hygroscopicity was evaluated according to Cai and Corke (2000) with some modifications. About $1.0 \mathrm{~g}$ of sample was placed into aluminum vials, weighed and equilibrated over saturated $\mathrm{NaCl}$ solution (providing relative humidity of $75.3 \%$ ) in hermetic container at $25^{\circ} \mathrm{C}$. Samples were weighed after one week, and hygroscopicity was expressed as $\mathrm{g}$ of adsorbed moisture/100 $\mathrm{g}$ of solids.

\section{Carotenoids Content (CC)}

Carotenoids content of the powders (mg carotenoids/g solids of pequi) was determined according to Rodrigues-Amaya (1999), based on acetone extraction and separation into petroleum ether. The absorbance was measured using a spectrophotometer at $450 \mathrm{~nm}$, corresponding to the wavelength of the prevalent carotenoid of pequi $\beta$ carotene.

\section{Vitamin C Content (VC)}

Vitamin $\mathrm{C}$ of the powders (mg vitamin $\mathrm{C} / \mathrm{g}$ solids of pequi) was obtained according to AOAC (2006), which was based on the reduction of the indicator 2,6-dichlorophenolindophenol (DCFI) by ascorbic acid.

\section{Bulk and Absolute Densities}

About $2.0 \mathrm{~g}$ of powder were placed in a $10 \mathrm{ml}$ graduated cylinder (readable to $1.0 \mathrm{ml}$ ). The cylinder was tapped by hand 50 times and the bulk density was calculated by dividing the mass of powder by the volume occupied in the cylinder (Goula et al. 2004). The measurements were carried out at room temperature. The absolute density of the powders was determined at $25^{\circ} \mathrm{C}$ using a helium Pycnometer Automatic Gas (AccuPyc 1330, Micromeritics, Norcross, USA).

\section{Porosity}

The porosity was calculated by Equation (4) (Krokida and Maroulis 1997).

$\varepsilon=1-\frac{\rho_{\mathrm{b}}}{\rho_{\mathrm{a}}} \times 100$

where $\rho_{\mathrm{b}}$ and $\rho_{\mathrm{a}}$ are the bulk and absolute densities, respectively. 
Particles Size Distribution

The particles size distribution was measured using a laser light scattering analyzer Mastersizer S (Malvern Instruments, Malvern, U.K.). A small quantity of powder was dispersed in $99 \%$ isopropanol and the particle size distribution was monitored during five successive readings. The particle size was expressed as the mean volumetric size D[4,3] (De Brouckere mean diameter), which represents the mean diameter of a sphere with the same volume, and is generally used to characterize a particle.

\section{Particles Morphology}

The particles microstructures were evaluated by scanning electron microscopy (SEM). Powders were attached to SEM stubs using a double-sided adhesive tape, coated with gold/palladium under a vacuum in a sputter coater (model SC7620, VG Microtech, Ringmer, UK) at a coating rate of 0.51 $\mathrm{A} \% \mathrm{~s}, 3-5 \mathrm{~mA}, 1 \mathrm{~V}$, at $0.08-0.09 \mathrm{mbar}$ for $180 \mathrm{~s}$. The coated samples were examined by a scanning electron microscope (LEO440i model, Leica Electron Microscopy Ltd., Oxford, England). The
SEM was carried out at $20 \mathrm{kV}$ and $150 \mathrm{pA}$ with a magnification of $3,000 \times$ and $5,000 \times$.

\section{RESULTS AND DISCUSSION}

\section{Experimental Design}

The experimental data were obtained using 17 combinations of the independent variables, inlet air temperature, surfactant and maltodextrin concentrations, as shown in Table 1 . The results from the experimental design were fitted to a second-order regression model (Eq. 1). The regression coefficients and coefficient of determination $\left(\mathrm{R}^{2}\right)$ are presented in Table 2 . The non-significant terms $(\mathrm{p} \geq 0.10)$ were eliminated and the models were tested for adequacy and goodness of fit by analysis of variance (ANOVA). When the calculated $\mathrm{F}$ value is greater than the tabulated $\mathrm{F}$ value, the variation is explained by the regression and not by the residues. Thus, the regression is significant and the model can be considered predictive.

$\underline{\text { Table } 2 \text { - Coded second-order regression coefficients and analysis of variance for experimental design responses. }}$

\begin{tabular}{ccccccccc}
\hline $\begin{array}{c}\text { Regression } \\
\text { coefficients }\end{array}$ & $\mathbf{Y}$ & $\mathbf{T}_{\text {out }}$ & $\boldsymbol{\eta}(\boldsymbol{\%})$ & $\mathbf{X}$ & $\mathbf{A}_{\mathbf{w}}$ & $\mathbf{H}$ & $\mathbf{V C}$ & $\mathbf{C C}$ \\
\hline$\beta_{0}$ & 42.17 & 110.63 & 41.72 & 0.27 & 0.14 & 12.02 & 200.72 & 41.53 \\
$\beta_{1}$ & $\mathrm{NS}$ & 12.89 & $\mathrm{NS}$ & $\mathrm{NS}$ & $\mathrm{NS}$ & 0.42 & $\mathrm{NS}$ & -9.20 \\
$\beta_{2}$ & $\mathrm{NS}$ & $\mathrm{NS}$ & $\mathrm{NS}$ & $\mathrm{NS}$ & $\mathrm{NS}$ & $\mathrm{NS}$ & -62.67 & -11.77 \\
$\beta_{3}$ & $\mathrm{NS}$ & $\mathrm{NS}$ & $\mathrm{NS}$ & $\mathrm{NS}$ & $\mathrm{NS}$ & $\mathrm{NS}$ & $\mathrm{NS}$ & -11.77 \\
$\beta_{11}$ & $\mathrm{NS}$ & 4.89 & -3.52 & 0.26 & $\mathrm{NS}$ & $\mathrm{NS}$ & - & - \\
$\beta_{22}$ & $\mathrm{NS}$ & 4.36 & -3.05 & 0.25 & $\mathrm{NS}$ & $\mathrm{NS}$ & - & - \\
$\beta_{33}$ & $\mathrm{NS}$ & $\mathrm{NS}$ & $\mathrm{NS}$ & $\mathrm{NS}$ & $\mathrm{NS}$ & -0.52 & - & - \\
$\beta_{12}$ & $\mathrm{NS}$ & $\mathrm{NS}$ & $\mathrm{NS}$ & $\mathrm{NS}$ & $\mathrm{NS}$ & $\mathrm{NS}$ & $\mathrm{NS}$ & $\mathrm{NS}$ \\
$\beta_{13}$ & $\mathrm{NS}$ & $\mathrm{NS}$ & $\mathrm{NS}$ & $\mathrm{NS}$ & $\mathrm{NS}$ & $\mathrm{NS}$ & $\mathrm{NS}$ & $\mathrm{NS}$ \\
$\beta_{23}$ & $\mathrm{NS}$ & $\mathrm{NS}$ & $\mathrm{NS}$ & $\mathrm{NS}$ & $\mathrm{NS}$ & $\mathrm{NS}$ & 10.95 & $\mathrm{NS}$ \\
\hline $\mathrm{R}^{2}$ & $\mathrm{NS}$ & 0.91 & 0.63 & 0.38 & $\mathrm{NS}$ & 0.29 & 0.93 & 0.84 \\
$\mathrm{~F}_{\mathrm{c}}$ & $\mathrm{NS}$ & 41.43 & 11.92 & 4.35 & $\mathrm{NS}$ & 2.89 & 56.28 & 12.37 \\
$\mathrm{~F}_{\mathrm{t}}$ & $\mathrm{NS}$ & 2.56 & 2.73 & 2.73 & $\mathrm{NS}$ & 2.73 & 3.11 & 3.07 \\
\hline
\end{tabular}

$\overline{\beta \mathrm{i}:}$ the estimated regression coefficient for the main linear effects. $\overline{\beta i i}$ t the estimated regression coefficient for the quadratic effects; $\overline{\beta i j}$ : the estimated regression coefficient for the interaction effects. $i=1$ : inlet air temperature; $i=2$ : surfactant concentration; $i=3:$ maltodextrin concentration. NS: Non-significant $(\mathrm{p}>0.10)$.

Dryer Performance: Process Yield, Outlet Air Temperature and Energetic Efficiency

The outlet air temperature is an important spray drying parameter, related to the energy consumption of dryer and the powder quality. If $\mathrm{T}_{\text {out }}$ is greater than $\mathrm{Tg}$, the powder can be sticky. The higher the temperature difference between them, the higher the degree of stickiness would be, reducing, therefore the powder recovery. Although process yield did not significantly change with spray drying conditions ( $\mathrm{p}>0.1$ ) (Table 2$)$, the $\mathrm{T}_{\text {out }}$ was influenced mainly by the $\mathrm{T}_{\text {in }}$ (Fig. 1), which was expected.

Energetic efficiency is commonly used to evaluate the dryer performance and to optimize the spray drying process, since its indicates the efficiency on heat transfer process between air-drying and the atomized fluid. The values found in this work 
varied from 29.9 to $44.8 \%$ (Table 1), which were similar to those reported by spray drying of Bidens pilosa L. extract (Cortés-Rojas et al. 2015). The experimental data were fitted by a second order polynomial model; however, as the coefficient of determination $\left(\mathrm{R}^{2}\right)$ of the adjusted model was only 0.63 , the model and the response surface could not be obtained. An inverse relationship between the energetic efficiency and outlet air temperature was observed (Fig. 2). According to Cortéz-Rojas et al. (2015), this could be explained by the fact that when higher drying temperatures are employed, the heat transfer is faster due to a higher heat evaporation capacity of the air; however, the heat losses to the environment increase.

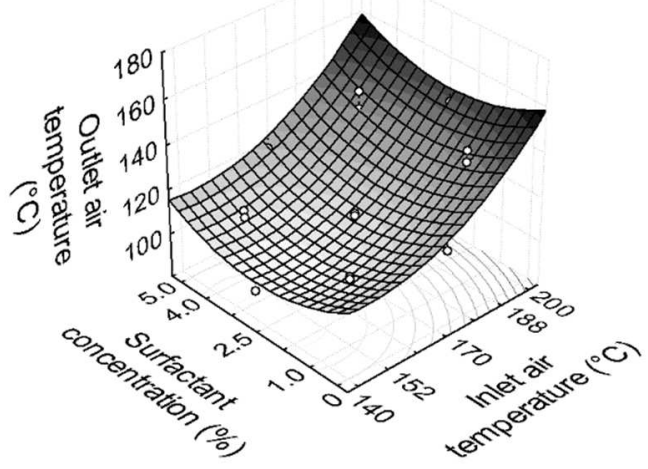

Figure 1 - Influence of independent variables on outlet air temperature.

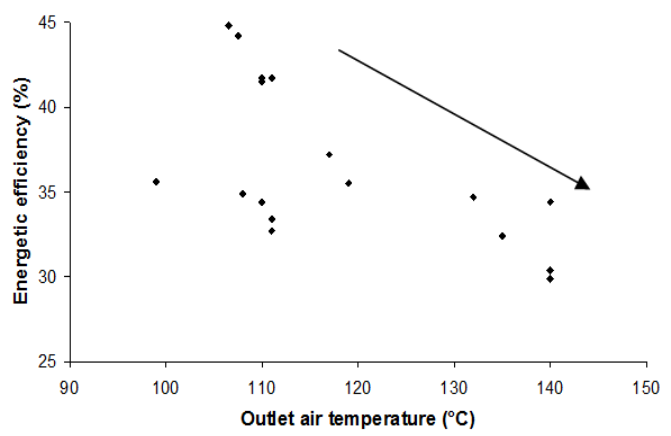

Figure 2 - Relationship between the responses energetic efficiency and outlet air temperature.

Powders Moisture Content and Water Activity Moisture content and water activity are important index since they can greatly affect the shelf-life of the powders. Water activity is different from the moisture content as it measures the availability of free water in a food system that is responsible for any biochemical reactions, whereas the moisture content represents the water composition in a food system. Thus, the higher water activity, the shorter food shelf-life. Since water activity values varied from 0.06 to 0.21 (Table 1), which were below 0.30 , the spray dried pequi pulp could be considered stable (Fennema 1996).

Moisture content of the spray-dried products is an indicator of the adequacy of the drying process. Lower residual moisture content limits the ability of water to act as a plasticizer and to depress the $\mathrm{Tg}$. As Tg of particles is a function of moisture content, the inlet variables become an important factor, because they affect the powder stickiness and caking. The Tg has also been used as indicator of the molecular mobility, which changes the diffusivity of molecular species. In the rubbery state, the molecular mobility of the matrix and the reactants are accelerated, which results in an increased rate of physicochemical properties of the products (Roos 2010). The powder moisture contents in the spray-dried powders in the present study varied from 0.25 to $1.43 \%$.

Although water activity of the powders did not significantly change with spray drying conditions (p>0.1) (Table 2), their moisture content was influenced by the inlet air temperature and surfactant concentration (Table 2). As the quadratic factors of these independents variables showed positive effect, increasing temperatures, or surfactant concentrations led to the minimum moisture content up to certain values of these parameters; above them, an opposite behavior was observed. Increasing inlet air temperature results a larger temperature gradient between the atomized feed and the air-drying. Thus, a higher heat transfer into the particles and, as consequence, higher evaporation rate occur. Fazaeli et al. (2012) and Tonon et al. (2008) also observed this behavior, studying the spray drying of black mulberry and açai, respectively. At higher temperatures, an increase in this process parameter led to the formation of wetter particles. This behavior could be attributed to the higher contraction of particle structure, forming a surface of higher thickness, and to the faster crust formation. These facts hinder the diffusion of water inside the particle, thus reducing the water evaporation, and resulting in the particles with higher moisture content. When the evaporation rate is higher a saturated atmosphere with water vapor can be formed on superficial particles, which also interferes on the diffusion of water from 
interior of the particle to drying air. As a consequence, higher temperatures can get wetter particles. This behavior was also observed for the microencapsulated coffee oil by spray drying as reported by Frascareli et al. (2012).

The experimental data were fitted by a second order polynomial model. As the coefficient of determination $\left(\mathrm{R}^{2}\right)$ of the adjusted model was only 0.383 , the model and the response surface could not be obtained.

\section{Powders Hygroscopicity}

The hygroscopicity values of the powder varied from 9.1 to $12.1 \mathrm{~g}$ water adsorbed/100 $\mathrm{g}$ solids (Table 1). These values were lower than those obtained by Moreira et al. (2009) and Tonon et al. (2008) for acerola and açai pulp with maltodextrin, respectively. Probably, this was due to the higher lipid content of pequi. Table 2 shows the influence of inlet air temperature and maltodextrin concentration on the powder hygroscopicity. This response was positive and linearly affected by the temperature, which could be related to the moisture content of the powder. Particles with lower moisture content are more hygroscopic, i.e., they have higher capacity to adsorb the moisture from surrounding air. An inverse relationship between the moisture content of the powder and hygroscopicity can be seen in Figure 3. The same behavior was reported by Goula et al. (2004) in their work about spray drying of tomato pulp.

Several studies have showen a reduction in the microcapsules hygroscopicities when maltodextrins are incorporated into the matrix (Tonon et al. 2008; Bhusari et al. 2014; Mishra et al. 2014). This may be due to the high hygroscopicity of small molecular sugars and organic acids present in the fruit juices. Since the $\mathrm{Tg}$ increases with increase in molecular weight, the addition of maltodextrin to the feed solution contributed significantly to powder stability, increasing the $\mathrm{Tg}$ of the powder, and consequently reducing the hygroscopicity (Roos and Karel 1991). However, for pequi pulp powder, this behavior was not observed. As the quadratic maltodextrin concentration parameter presented a significant negative behavior (Table 2), i.e., hygroscopicity increased with maltodextrin concentration until the response reached a maximum value; then, its reduction was observed. Frascareli et al. (2012) evaluated the influence of oil concentration on the microencapsulation of coffee oil by spray drying using gum Arabic as wall material. They found higher hygroscopicity when the lower oil concentration (and consequently higher gum Arabic content) was used, which was expected, since coffee oil is a hydrophobic material, which does not adsorb water, and to the hygroscopic nature of gum Arabic when compared to coffee oil. Therefore, as pequi pulp has a high content of sugars, which contributes to increase hygroscopicity, and a high fat content $(30.7 \%)$ that does not adsorb water, it was difficult to analyze how the addition of maltodextrin could influence on the hygroscopicity of the powder.

The experimental data were fitted by a second order polynomial model. The coefficient of determination $\left(\mathrm{R}^{2}\right)$ of the adjusted model was 0.292 , indicating that the model explained only $29.2 \%$ of the total variation. Therefore, the model and the response surface could not be obtained.

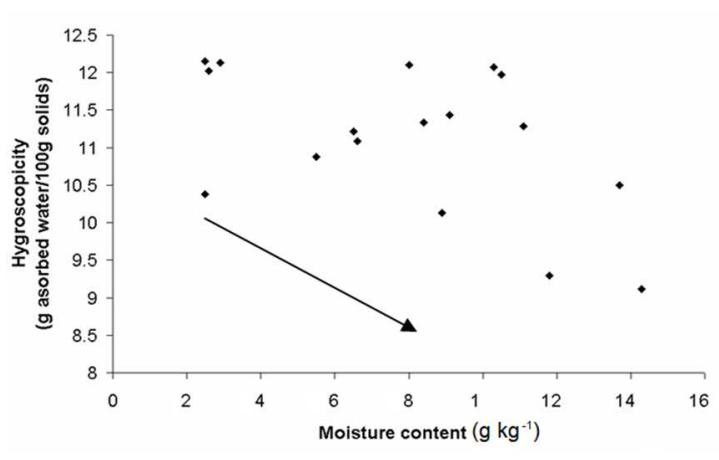

Figure 3 - Relationship between the responses powder moisture content and hygroscopicity.

\section{Powders Vitamin $C$ and Total Carotenoids Contents}

Table 1 showed the powders vitamin $\mathrm{C}$ and carotenoids content values, which ranged from 129.8 to $303.0 \mathrm{mg} / \mathrm{g}$ solids of pequi and 12.4 to 94.9 $\mathrm{mg} / \mathrm{g}$ solids of pequi, respectively. Both nutrient concentrations were influenced negatively by the surfactant concentration (Figs. 4 and 5A).

Several preliminaries tests without surfactant on feed solution have shown that there was not freeflowing microcapsules formation by spray drying. According to Thies (2001), it is essential that the emulsion is stable before and during the spray drying to occur the microcapsules formation. Since maltodextrin has low emulsifying capacity and pequi pulp presents high lipid content, Tween 80 was utilized as surfactant to obtain a stable emulsion and, consequently, microcapsules powder protected better the nutrients of pequi pulp. 


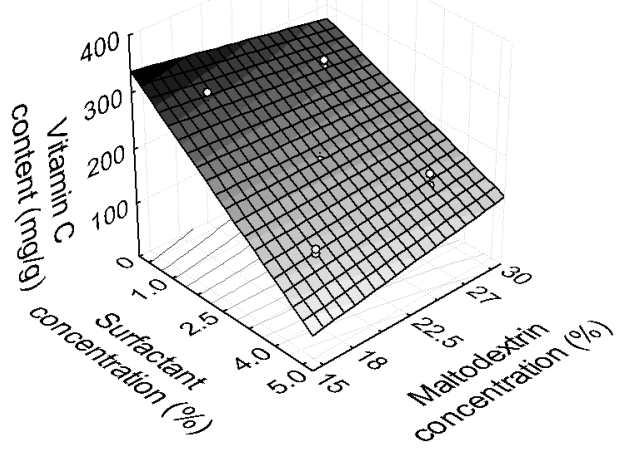

Figure 4 - Influence of independent variables on powders vitamin $\mathrm{C}$ content.

McClements (2006) pointed out that there must be a sufficient quantity available of surfactant to completely cover all the droplets formed in the emulsion. In addition, several authors have reported that emulsifier content is negatively related with the emulsion droplet size (Jafari et al. 2008; Frascareli 2012). Since lower emulsion droplet size leads to higher encapsulation efficiency, it is expected that high surfactant concentration resulted in a better nutritional retention after spray drying. However, in this study, nutrients retentions were not achieved successfully at higher surfactant concentrations. Zhang and Zhu (2004) reported that bovine serum albumin (BSA)-loaded poly(D,Llactic-co-glycolic acid) (PLGA) microspheres were prepared successfully using Tween 80 as emulsifier at several concentrations. However, microspheres were not obtained when the Tween 80 content was higher than $2 \%$. In addition, the authors observed that the BSA entrapment efficiency increased (reaching 25\%) firstly as the Tween 80 concentration was enhanced up to $0.1 \%$; however, at above this value, there was a decrease from 25 to $10 \%$ of efficiency (at $0.5 \%$ Tween 80 concentration). Laugel et al. (1996) verified an existence of an emulsifier optimal concentration: lower concentrations were not sufficient to stabilize the emulsion, and higher concentrations, mainly above the critical micelle concentration, led to a destabilization of emulsions.

Figure 5 showed that air temperature had a significant and negative effect on carotenoid content. This behavior was expected, since the chemical structure of carotenoids is very susceptible to heat destruction and oxidation. However, temperature did not take affect the vitamin $\mathrm{C}$ degradation of pequi pulp powder (Table 2), despite the literature reports that the increment in temperature results in a degradation of vitamin C (Hal et al. 2012; Solval et al. 2012). The concentration of maltodextrin concentration had a little effect on vitamin C content. However, carotenoid content suffered a negative influence (Fig. 5B), probably due to the fact that high maltodextrin concentrations do not favor the formation of stable emulsion, and consequently, microcapsules powder, thus reducing the protective effect.
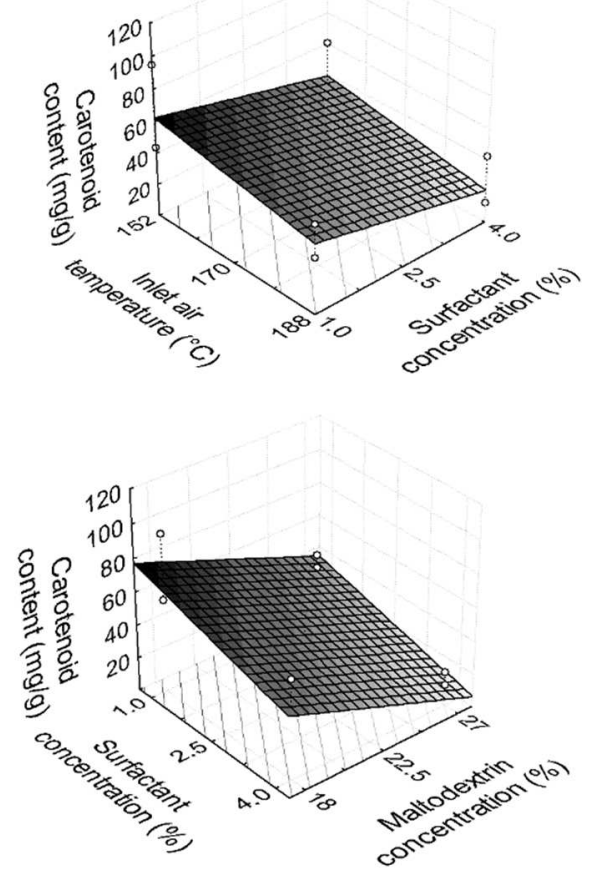

Figure 5 - Influence of independent variables on powders carotenoid content: (a) inlet air temperature $\times$ surfactant concentration; (b) maltodextrin concentration temperature $x$ surfactant concentration.

\section{Characterization of the Pequi Spray-dried Obtained Under the Optimum Condition}

Optimization of the spray drying of pequi pulp was carried out using response surface methodology for the maximum values of vitamin $\mathrm{C}$ and total carotenoids content. Combining all the optimal regions of the Figures 4 and 5, a inlet air temperature of $152^{\circ} \mathrm{C}$ and feed composition of $1 \%$ of Tween 80 and $18 \%$ of maltodextrin were chosen as optimized condition for both responses. Validation tests were performed to determine the adequacy the polynomial models (Table 2). 
According to these models, the predicted results for vitamin $C$ and carotenoid content (274.37 and 74.27 $\mathrm{mg} / \mathrm{g}$ solids pequi, respectively), obtained under the optimum condition, were close to the experimental responses observed (309.92 \pm 0.38 and $68.02 \pm 0.84$ $\mathrm{mg} / \mathrm{g}$ solids pequi, respectively). Therefore, there was a good fit between the predicted results and the experimental responses, with an average relative error of $11 \%$ and $9 \%$ for the vitamin $\mathrm{C}$ and carotenoid content, respectively. Although some responses did not significantly change with spray drying conditions ( $>0.1)$ and some models were not obtained due to the low coefficient of determination, moisture content, hygroscopicity, process yield and water activity of pequi pulp powder were also determined: $0.86 \pm 0.02 \%, 10.34$ $\pm 0.02 \mathrm{~g}$ adsorbed water $/ 100 \mathrm{~g}$ solids, $46.63 \pm 0.12 \%$ and $0.10 \pm 0.01$, respectively.

\section{Particles Size Distribution}

The pequi pulp powder obtained under the conditions as above was characterized in terms of particles size distribution, bulk and absolute densities, porosity and microcapsules morphology. The mean diameter particles of pequi pulp powder $(\mathrm{D}[4,3])$ was $9.5 \pm 0.3 \mu \mathrm{m}$. This indicated that spray drying does not produce large particles. This physical property is very important in respect to the rehydration, since the lower the particle size, the lower would be the solubility and flowability of the powder. According to Hogekamp and Schubert (2003), the presence of fine particles in particulate systems can result in poor instantaneous properties, since the reduction of interstices can difficult the penetration of water, adversely affecting powder wettability and dispersibility. In addition, as particle size decreases, the increase in the total particle surface area causes higher affinity to moisture content and ability to suffer caking during drying process as well as during storage (Tóth and Pallai-Varsányi 2006).

Figure 6 shows the particle size distribution of the pequi pulp powder. A bimodal distribution was observed, in which there were two distinct peaks, indicating two predominant sizes. One of them corresponded to lower diameter (approximately 0.5 $\mu \mathrm{m})$ and presented a lower volume $(<1 \%)$. The major peak had a mean diameter close to $10 \mu \mathrm{m}$. According to Tonon et al. (2008), this bimodal distribution is particularly interesting for particulate systems, since smaller particles can penetrate into the spaces between the larger ones, thus occupying less space. A compaction and segregation of a mixture can occurred, where smaller particles remain at the bottom and larger particles at the top (O'Hagan et al. 2005). The presence of larger particles $(60-110 \mu \mathrm{m})$ could be associated to the beginning of agglomeration, due to the formation of irreversible link bridges.

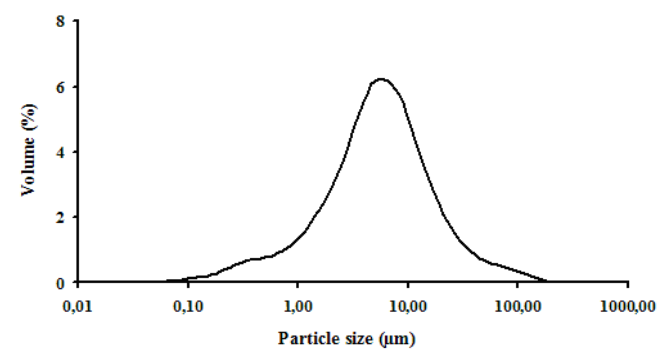

Figure 6 - Particle size distribution of spray-dried pequi powder.

\section{Bulk and Absolute Density and Porosity}

Bulk and absolute densities, and porosity of the pequi pulp powder were $420.0 \pm 0.03 \mathrm{~g} / \mathrm{L}$, $1280.0 \pm 0.01 \mathrm{~g} / \mathrm{L}$, and 0.68 , respectively. Osório and Carriazo (2011) and Horuz et al. (2012) observed similar results for the powders of guava and pomegranate juice, respectively. Caparino et al. (2012) reported higher values of bulk density for mango pulp powder than for pequi powder.

For packaging and shipping considerations, the knowledge of bulk density is of fundamental importance, because its shows how much material, by weight, will fit into a container. Thus, lower bulk density of product is not interesting, which requires a larger volume of package. As the bulk density is related to the porosity, the lower the bulk density, the more would be occluded air within the powders and, therefore, a greater possibility for product oxidation, reducing storage stability (Reineccius 2001). To minimize these drawbacks, it is possible to obtain the powders with higher bulk just controlling spray drying conditions. At high feed solids concentration and drying rates (due to high inlet air temperatures), there is a fast surface crust formation. A vacuole forms within the particle and inflates once the particle temperature exceeds the local ambient boiling point and the vapor pressure within the vacuole rises above the local ambient pressure (Bhandari et al. 1992; Walton 2000; Nijdam and Langrish 2006).

\section{Scanning Electron Microscopy}

The pequi pulp powder morphology was evaluated by scanning electron microscopy (SEM) (Fig. 7). The particles showed spherical and several sizes, 
which is characteristic of the powders produced by spray drying. The particles presented a continuous wall and absence of fissures, cracks, or collapses. Smooth and spherical particles are desirable because there is a good aroma retention and ingredient stability (lowest surface:volume ratio), higher bulk density (best packing) and good flowability (Reineccius 2001).

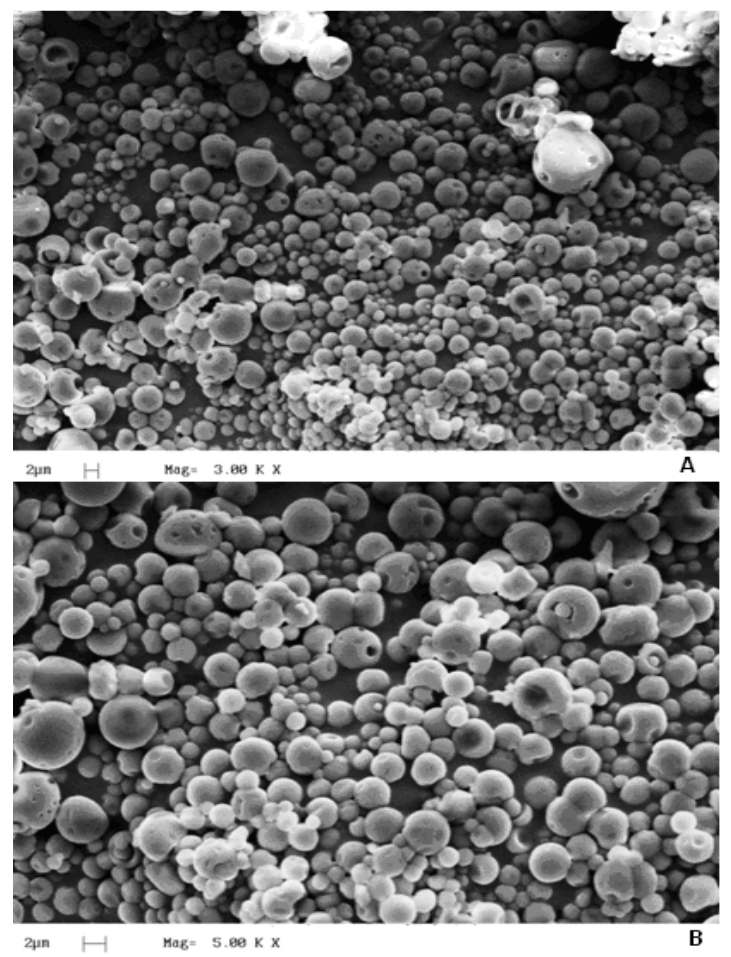

Figure 7 - Micrographs of spray-dried of pequi pulp powder. Images with magnifications of $3,000 \times(\mathrm{A})$ and $5,000 \times(\mathrm{B})$.

\section{CONCLUSIONS}

The results reported in this work demonstrated the effect of temperature and feed concentration on the quality of the powder and dryer performance. Only water activity and process yield were not influenced significantly by these variables $(p>0.1)$. The optimization of spray drying in respect to vitamin C and carotenoid content was needed in order to obtain a powder with high nutritional quality. Response surface methodology was adequate to obtain the optimum condition: inlet air temperature of $152^{\circ} \mathrm{C}$, surfactant concentration of $1 \%$ and maltodextrin concentration of $18 \%$. These conditions led to a vitamin $\mathrm{C}$ and carotenoid content of $309.92 \pm 0.38$ and $68.02 \pm 0.84 \mathrm{mg} / \mathrm{g}$ solids pequi, respectively. The particles showed no fissure, surface cracks, or collapses, which is desirable. This work showed that powder properties and dryer performance should be considered simultaneously to evaluate the spray drying process. The results could be useful for food and cosmetic industries, which are looking for novel and inexpensive sources of natural pigments and flavorings.

\section{ACKNOWLEDGMENTS}

The authors acknowledge Foundation of Research Support of São Paulo (FAPESP) and Faculty of Agricultural Engineering - University of Campinas (FEAGRI-UNICAMP) for financial support.

\section{REFERENCES}

AOAC. Official Methods of Analysis. 18. ed. Gaithersburg: Association of Official Analytical Chemists, 2006.

Barbosa-Canovas GV, Ortega-Rivas E, Juliano P, Yan H. Food Powders: Physical Properties, Processing, and Functionality. 1. ed. New York: Kluwer Academic/Plenum Publishers, 2005. 381p.

Bhandari BR, Dumoulin ED, Richard HMJ, Noleau I, Lebert AM. Flavor encapsulation by spray drying: application to citral and linalyl acatate. J Food Sci. 1992; 57: 217-221.

Bhusari SN, Muzaffar K, Kumar P. Effect of carrier agents on physical and microstructural properties of spray dried tamarind pulp powder. Powder Technol. 2014; 266: 354-364.

Cai YZ, Corke H. Production and properties of spraydried Amaranthus betacyanin pigments. J Food Sci. 2000; 65: 1248-1252.

Caparino OA, Tang J, Nindo CI, Sablani SS, Powers JR, Fellman JK. Effect of drying methods on the physical properties and microstructures of mango (Philippine Carabao var.) powder. J Food Eng. 2012; 111: 135148.

Cortés-Rojas DF, Souza CRF, Oliveira WP. Optimization of spray drying conditions for production of Bidens pilosa L. dried extract. Chem Eng Res Des. 2014; 93: 366-376.

Fazaeli M, Emam-Djomeh Z, Ashtari AK, Omid M. Effect of spray drying conditions and feed composition on the physical properties of black mulberry juice powder. Food Bioprod Process. 2012; 90: 667-675.

Fennema OR. Water and ice. In: Fennema OR, editor. Food Chemistry. New York: Marcel Dekker; 1996. p. 17-94.

Frascareli EC, Silva VM, Tonon RV, Hubinger MD. Effect of process conditions on the microencapsulation 
coffee oil by spray drying. Food Bioprod Process. 2012; 90: 413-424.

Goula AM, Adamopoulos KG, Kazakis NA. Influence of spray drying conditions on tomato powder properties. Dry Technol. 2004; 22: 1129-1151.

Hal PH-V, Bosschaart C, Twisk CV, Verkerk R, Dekker M. Kinetics of thermal degradation of vitamin $C$ in marula fruit (Sclerocarya birrea subsp. caffra) as compared to other selected tropical fruits. LWT-Food Sci Technol. 2012; 49: 188-191.

Hogekamp S, Schubert H. Rehydration of food powders. Food Sci Technol Int. 2003; 9: 223-235.

Jafari SM, Assadpoor E, Bhandari B, He Y. Nanoparticle encapsulation of fish oil by spray drying. Food Res Int. 2008; 41: 172-183.

Horuz E, Altan A, Maskan M. Spray drying and process optimization of unclarified pomegranate (Punica granatum) juice. Dry Technol. 2012; 30: 787-798.

Krinsky NI, Johnson EJ. Carotenoid actions and their relation to health and disease, Mol Aspects Med. 2005; 26: 459-516.

Krokida MK, Maroulis ZB. Effect of drying method on shrinkage and porosity. Dry Technol. 1997; 15: 24412458.

Laugel C, Chaminade P, Baillet A, Seiller M, Ferrier D. Moisturizing substances entrapped in $\mathrm{W} / \mathrm{O} / \mathrm{W}$ emulsions: analytical methodology for formulation, stability and release studies. J Control Release. 1996; 38: 59-67.

Masters K. Spray drying handbook. 5. ed. London: Longman Scientific and Technical, 1991. 696p.

McClements DJ. Food emulsions: Principles, practice, and techniques. 2. ed. Boca Raton: CRC Press, 2005. $614 \mathrm{p}$.

Mishra P, Mishra S, Mahanta CL. Effect of maltodextrin concentration and inlet air temperature during spray drying on physicochemical and antioxidant properties of amla (Emblica officinalis) juice powder. Food Bioprod Process. 2014; 92: 252-258.

Moreira GEG, Costa MGM, Souza ACR, Brito ES, Medeiros MFD, Azeredo HMC. Physical properties of spray dried acerola pomace extract as affected by temperature and drying aid. LWT-Food Sci Technol. 2009; 42: 641-645.

Nijdam JJ, Langrish TAJ. The effect of surface composition on the functional properties of milk powders. J Food Eng. 2006; 77: 919-925.

O'Hagan P, Hasapidis K, Coder A, Helsing H, Pokrajac G. Particle size analysis of food powders. In: Onwulata C, editor. Encapsulated and Powdered Foods. Boca Raton: Taylor and Francis; 2005. p. 215-246.

Osório C, Carriazo JG. Thermal and structural study of guava (Psidium guajava L) powders obtained by two dehydration methods. Quim Nova. 2011; 34: 636-640.

Reineccius GA. Multiple-core encapsulation: encapsulation materials. In: Vilstrup $\mathrm{P}$, editor. Microencapsulation of food ingredients. Surrey: Leatherhead Publishing; 2001. p. 151-185.
Rodrigues-Amaya DB. Quantitative analysis, in vitro assessment of bioavailability and antioxidant activity of food carotenoids - A review. J Food Compos Anal. 2010; 23: 726-740.

Rodrigues-Amaya DB. Carotenoids and food preparation: the retention of provitamin A, carotenoids in prepared, processed and stored foods. 1. ed. Arlington: OMNI Project, 1999. 93p.

Roos YH. Glass transition temperature and its relevance in food processing. Annu Reviews Food Sci Technol. 2010; 1: 469-496.

Roos Y, Karel M. Water and molecular weight effects on glass transitions in amorphous carbohydrates and carbohydrate solutions. J Food Sci. 1991; 56: 16761681.

Santos PHS, Silva MA. Retention of vitamin C in drying processes of fruits and vegetables - A review. Dry Technol. 2008; 26: 1421-1437.

Soares, AG. Post-harvest losses of fruits and vegetables. In: Agribusiness Forum of University of Campinas Quality and Food Security, 2009, Campinas, Brazil (in Portuguese).

Solval KM, Sundararajan S, Alfaro L. Sathivel S. Development of cantaloupe (Cucumis melo) juice powder using spray drying technology. LWT-Food Sci Technol. 2012; 46: 287-293.

Teixeira MA. Babassu - A new approach for an ancient Brazilian biomass. Biomass Bioenergy. 2008; 32: 857864.

Thies C. Microencapsulation: What it is and purpose. In: Vilstrup P, editor. Microencapsulation of food ingredients. Surrey: Leatherhead Publishing; 2001. p. $1-30$.

Tonon RV, Brabet C, Hubinger MD. Influence of process conditions on the physicochemical properties of açai (Euterpe oleraceae Mart.) powder produced by spray drying. J Food Eng. 2008; 88: 411-418.

Tóth J, Pallai-Varsányi E. Drying of bovine serum albumin on inert particle surface in msb dryer. In: 15 th International Drying Symposium, 2006, Budapest.

Walton, DE. The morphology of spray-dried particles A qualitative view. Dry Technol. 2000; 18:1943-1986.

Zhang JX, Zhu, KJ. An improvement of double emulsion technique for preparing bovine serum albumin-loaded PLGA microspheres. Microencapsul. 2004; 21: 775785.

Received: July 02, 2015; Accepted: September 14, 2015. 